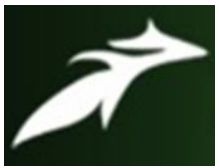

Gadona Enoch Alhamdu et al, International Journal of Advances in Agricultural Science and Technology,

Vol.7 Issue.11, November-2020, pg. 132-144

ISSN: 2348-1358

Impact Factor: 6.057

NAAS Rating: 3.77

\title{
MAPPING SOIL DEGRADATION IN MUBI/NORTH AND GOMBI LOCAL GOVERNMENTS AREA IN ADAMAWA STATE, NIGERIA
}

\author{
Gadona Enoch Alhamdu ${ }^{1}$; Elisha Tizhe Faive ${ }^{2}$; Gamaniel Japheth ${ }^{3}$ \\ Department of Surveying and Geoinformatics, Federal Polytechnic, Mubi, Adamawa State, Nigeria \\ DOI: 10.47856/ijaast.2020.v07i11.017
}

\begin{abstract}
Soil erosion is an ecological issue of great concern in the Northern part of Adamawa State. The research study adopts a combination of Geographic Information System (GIS) and Remote Sensing as a tool to study and map soil degradation in Mubi/North and Gombi local government areas of Adamawa State. For this research study, several datasets that represent climate, soil and anthropogenic factors were employed in mapping and analyzing soil degradation in the study area. Mapping of soil degradation for 1986 and 2016 and the Normalized Difference Vegetation Index for 1986 and 2016 was carried out. The results of the soil degradation maps of 1986 and 2016 and the NDVI of 1986 and 2016 shows the level of soil degradation and the vegetation depletion that occurred in the last twenty years (1986-2016). The research study demonstrates the integration of GIS with Remote Sensing as a tool for effective and efficient mapping of soil degradation.
\end{abstract}

Keywords: Soil Degradation, Normalized Difference Vegetation Index (NDVI) Remote Sensing, Mapping.

\section{Introduction}

Land is commonly used to refer to a section of the earth's surface with all the physical, chemical and biological features influencing the use of land. It thus comprises soil, terrain, climate, hydrology, vegetation and fauna, as well as human activities (land management) (Ann, 2002). Land degradation is a global issue for a number of reasons, but most significantly because productive land is one of several resources where decline in productivity threaten our capacity to feed a growing world population estimated to be over nine billion by 2050 Mick (2014). This assentation is buttressed by (Julian Crib, 2014) who point out that of the 1.5 billion hectares of global farm land a quarter is affected by serious degradation, up from $15 \%$ two decades ago. Land degradation is generally caused by inappropriate land use and management that jeopardizes soils self-regulatory capacity (and resistance and resilience). The unsustainable land use and management practice themselves are often driven by socio-economic and political forces (Lal, 1998). Human activities such as over cultivation, deforestation and others are some of the main causes of soil degradation(Abubakar,1995) observed that continues cultivation involves processes such as tillage, bush burning and harvesting which leads to soil degradation. In the 


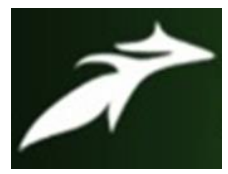

Gadona Enoch Alhamdu et al, International Journal of Advances in Agricultural Science and Technology, Vol.7 Issue.11, November-2020, pg. 132-144

ISSN: 2348-1358

Impact Factor: 6.057

NAAS Rating: 3.77

same vein (Guessess, Klik and Hurni,2009) observed that poor land use practice and lack of effective planning and implementation approach for soil conservation are responsible for accelerated degradation of Agricultural lands and siltation of dams and reservoirs downstream.

Many national, regional and global assessment and mapping of soil degradation were undertaken over the years, of all these studies one may conclude that many past statements were based on assertion that were unsubstantiated by hard evidence, in fact the influence of land degradation in economic terms continue to be debated ( Freddy, 2010). Lack of cause effective relationship between severity of degradation and productivity criteria for designing different classes of land degradation e.g Low, Medium and others is the major challenges. And lack of information between cover types and natural phenomenon such as climatic conditions and anthropogenic activities is the major challenges faced in Adamawa state.

In this research study, GIS and Remote Sensing techniques was adopted as an approach to map soil degradation in Adamawa state. The research work is seeking to unveil the soil degraded areas, also employed Normalized Difference Vegetation Index (NDVI). The aim is mainly to explore the possibility of using NDVI as a proxy to indirect assessment and mapping of soil degradation in the study area. Remote Sensing technique has often proved to be a veritable tool for modeling and estimating some biophysical parameters, and it's also a very important tool in mapping soil degradation, its repetitive, wide coverage and spatio temporal nature makes it a viable tool for mapping soil degradation of large areas. The specific objectives of this research study are:

1 To map soil degradation between 1986 and 2006 time period.

2 To carry out Normalized Difference Vegetation Index between 1986 and 2006

3 Determine and compare the degradation between this period and its effect on land management

4 To determine possible mitigation measures to reduce the effect of soil degradation.

\section{The Study Area}

Mubi/North and Gombi Local government areas of Adamawa State constitute the study area and are located in the Northeast Nigeria between latitudes $10^{\circ} 04^{\prime} 00^{\mathrm{n}} \mathrm{N}-10^{0} 14^{\prime} 15^{\prime \prime} \mathrm{N}$ and longitudes $13^{\circ} 40^{\prime} 30^{\prime \prime} \mathrm{E}-13^{0} 34^{\prime} 15^{\prime \prime} \mathrm{E}$ of the Greenwich meridian and for Gombi $10^{\circ} 5^{\prime} 15^{\prime \prime} \mathrm{N}-10^{\circ} 15^{\prime} 30^{\prime \prime} \mathrm{N}$ and longitudes $13^{0} 30^{\prime} 15^{\prime \prime} \mathrm{E}-13^{\circ} 30^{\prime} 45^{\prime \prime} \mathrm{E}$ of the Greenwich meridian. Gombi covers an area of about 2,232.03 $\mathrm{km}_{2}$ Mubi/North covers an area of about $495.64 \mathrm{~km}_{2}$ the area is boarded to the south by Song and to the north by Borno state. The area is further boarded to the east by 


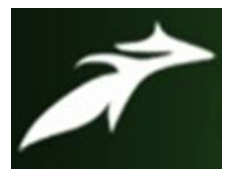

Gadona Enoch Alhamdu et al, International Journal of Advances in Agricultural Science and Technology, Vol.7 Issue.11, November-2020, pg. 132-144

ISSN: 2348-1358

Impact Factor: 6.057

NAAS Rating: 3.77

Mubi/North. Mubi/North is boarded to the south by Maiha and Mubi/South, the area is boarded to the north by Michika and to the east by Cameroun Republic.

The relief of the area is a combination of upland plains, lowlands, hills/mountain ranges, valleys and river planes. It has a tropical wet and dry climate. The rainfall pattern is strongly influenced and control by the movement of the Inter Tropical Discontinuity (ITD). The average rainfall for the state is $759 \mathrm{~mm}$; rainfall peak is witnessed between June and September. Wettest month are August and September. The length of the season averages eighty five to ninety two days per year, while dry season last from November to March.

Adamawa state is made up of three Ecological zones: namely, Southern Guinea savanna (4 local governments), 11) Northern Guinea savanna (6.local govt) and Sudan savanna made up of eleven local government areas...Mubi/North and Gombi were the two selected from the northern guinea savanna ecological zone.

The research would identify and map soil degradation and the Normalized Difference Vegetation Index (NDVI) for 1986 and 2006 time period and determine the extent of degradation and proffer mitigation measures.

\section{Materials and Methods}

In this research work, Remote Sensing and Geographic Information System (GIS) technique was adopted to achieve the stated aim and objectives. The primary data collected includes; Landsat Thematic Mapper TM of 1986 and 2006 with 30m resolution, downloaded from the Earth Explorer for the two selected local governments. ASTER Image (DEM), Advance Space borne Thermal Emission and Radiometer downloaded from GLCP. Secondary data,: journals, textbooks, population data obtained from National Population Commission (NPC) and rainfall data obtained from Upper Benue River Basin Development Authority (UBRBDA) Yola.

For mapping soil degradation, the Revised Universal Soil Loss Equation (RUSLE) was adopted; data used to evaluate RUSLE factors and generation of erosion map in the study area was obtained from the primary data. These data were processed using the maximum likelihood classification algorithm in Erdas Imagine and 3D ANALYST Extensions of ArcGIS 10.2. Rainfall distribution and soil erodibility Sharpe files were downloaded from ASTERGDEM. 


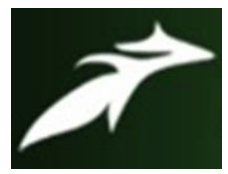

Gadona Enoch Alhamdu et al, International Journal of Advances in Agricultural Science and Technology,

Vol.7 Issue.11, November-2020, pg. 132-144

ISSN: 2348-1358

Impact Factor: 6.057

NAAS Rating: 3.77

\section{Rainfall Erosivity Factor $(\mathbf{R})$}

Precipitation readings in $\mathrm{mm}$ are needed and then processed through spatial Analyst/Interpolation spline. Average rainfall data for a period of twenty years (1986-2006) obtained from Nigerian metrological Agency (NIMA). Rainfall pattern in the study area ranges from $500 \mathrm{~mm}$ to $750 \mathrm{~mm}$, with an average rainfall of $600 \mathrm{~mm}$ annually.

\section{Slope Factor (LS)}

Derivation of slope factor (LS) Involved generation of Digital Elevation Model (DEM), thus the creation of slope, flow direction and flow accumulation. LS factor was determined using equation:

$\mathrm{LS}=(\mathrm{AS} / 22,13)(\mathrm{Sin} / 0.09)^{\mathrm{n}}$

Where AS = upslope contributing area per unit width of cell spacey

$\Theta=$ slope angle (degrees)

$\mathrm{M}$ and $\mathrm{n}=$ exponent of slope parameters for slope length and gradient value of $\mathrm{n}$ are 0 ...4-0.6 and 1.0-1.4. Where value of $\mathrm{m}=0.4$ and $\mathrm{n} 1.1$

\section{Land cover Factor (Cover Management)}

The classification of the study area was done through the classification of Landsat ETM+ using maximum likelihood analysis. The result of this classification was used to drive the Cfactor for the land cover.

\section{Soil Texture/Erodibility K- Factor}

Data obtained from the soil map with soil types. Data like silt, clay and sandy soil values were used. The L- Factor was the calculated for each soil texture class.

\section{Slope Length and Steepness}

Raster calculator was used to perform calculation here, with flow direction, flow accumulation slope to get F, M, LS Factors.

\section{Soil Degradation Map (A-Factor)}

Raster calculation was used to perform calculation by using RUSLE

$$
\mathrm{A}=\mathrm{R} \times \mathrm{K} \times \mathrm{LS} \times \mathrm{C} \times \mathrm{P}
$$

Where $A=$ Average soil loss

$\mathrm{R}=$ Rainfall erosivity factor

$\mathrm{K}=$ Soil erosivity factor 


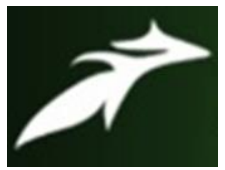

Gadona Enoch Alhamdu et al, International Journal of Advances in Agricultural Science and Technology,

Vol.7 Issue.11, November-2020, pg. 132-144

ISSN: 2348-1358

Impact Factor: 6.057

NAAS Rating: 3.77

$$
\begin{aligned}
& \mathrm{LS}=\text { Slope factor } \\
& \mathrm{C}=\text { Cover factor }
\end{aligned}
$$

Erosion is described as the wearing away of the earth surface material by wind, water, ice or gravity. One important fact remains that these data collected on soil erosion is capital intensive as well as time consuming. Remote sensing data provide better technique to solve this problem. Remote Sensing and GIS enable the manipulation and mapping of spatial data of various types. This include soil erosion, hence the adoption of remote sensing for mapping soil degradation in the selected two local government areas of Adamawa state for this research study.

\section{Results and Discussions}

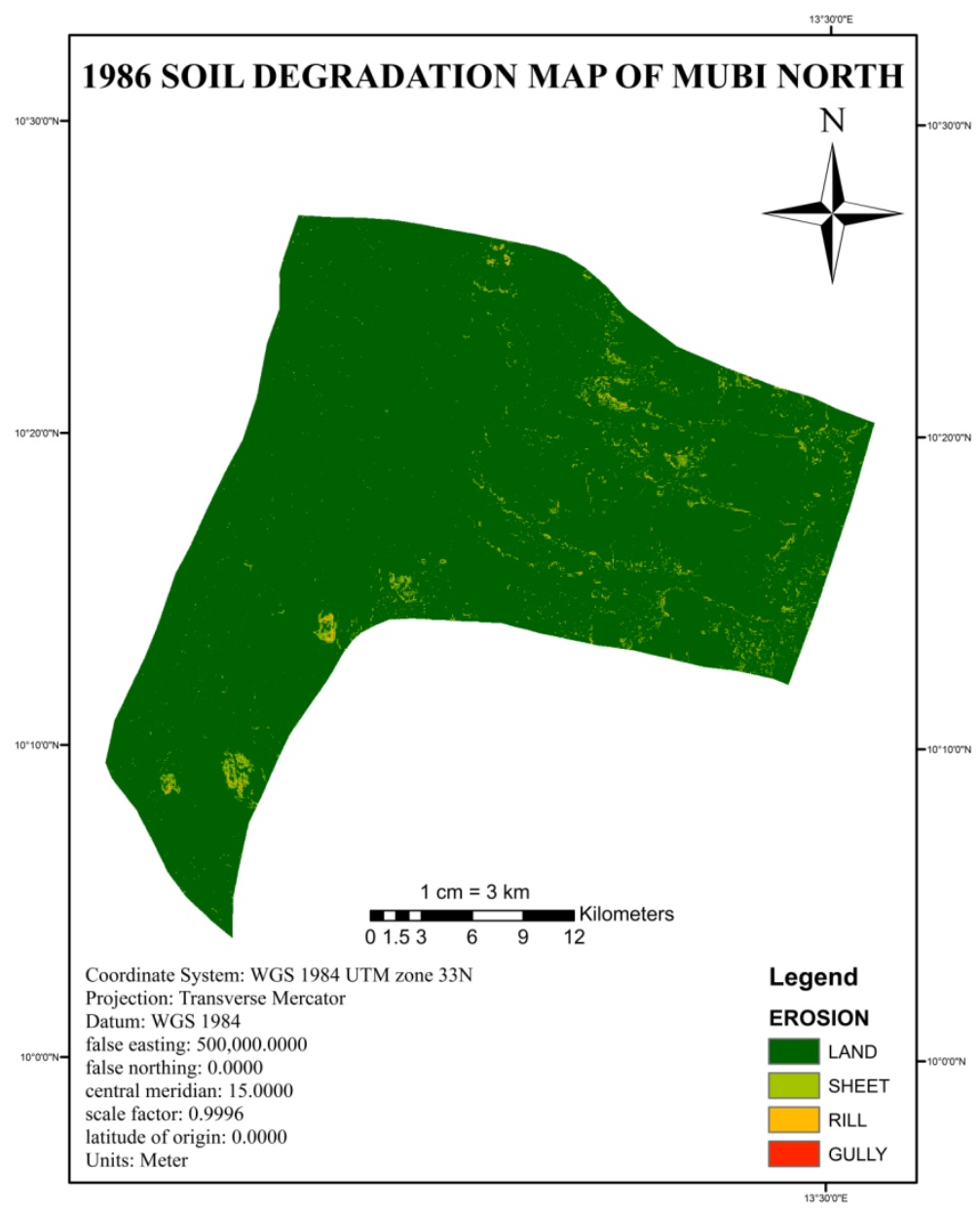




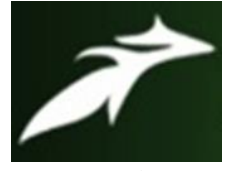

Gadona Enoch Alhamdu et al, International Journal of Advances in Agricultural Science and Technology,

Vol.7 Issue.11, November-2020, pg. 132-144

ISSN: 2348-1358

Impact Factor: 6.057

NAAS Rating: 3.77

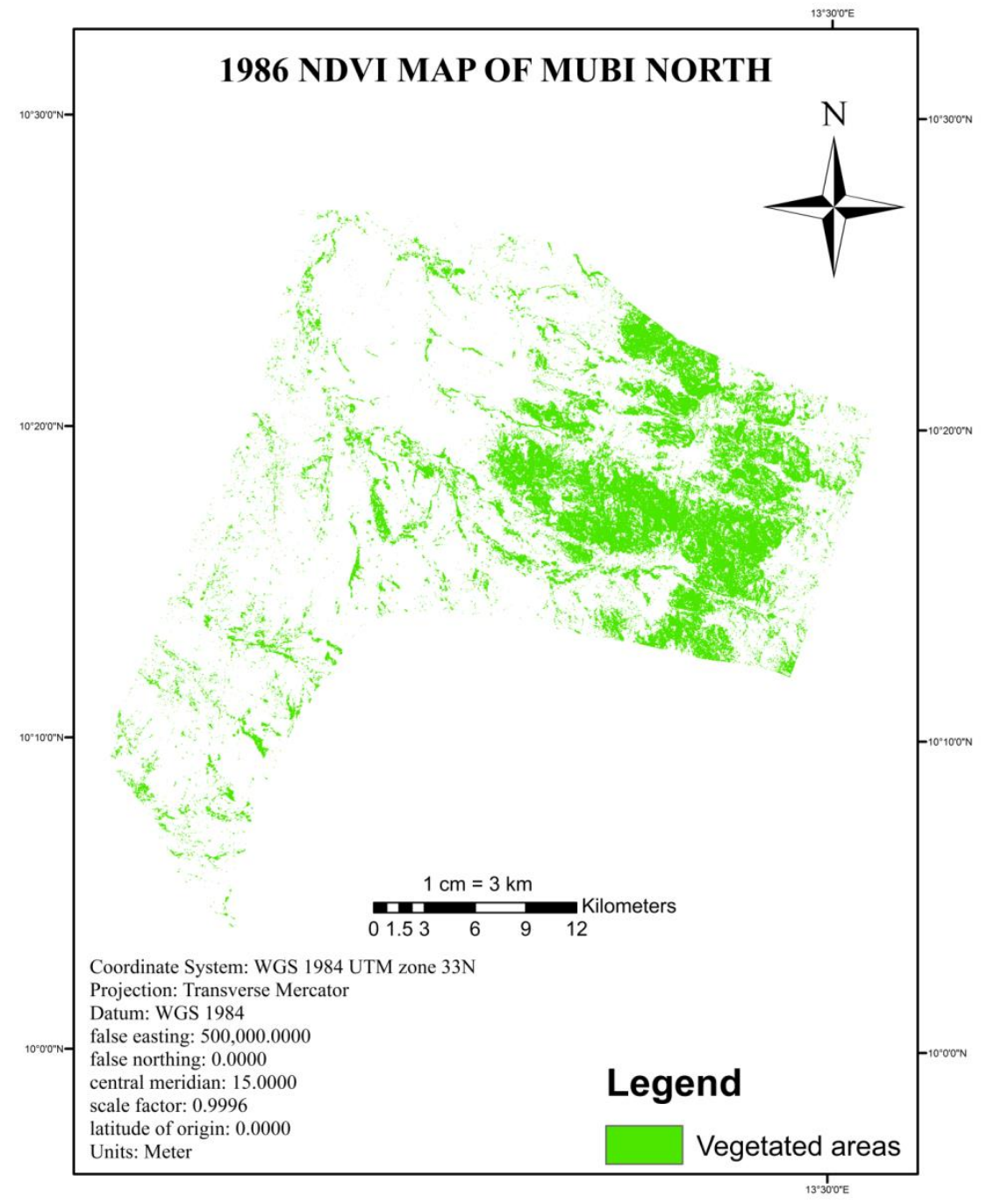




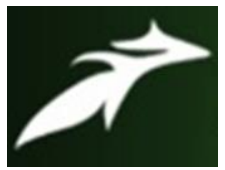

Gadona Enoch Alhamdu et al, International Journal of Advances in Agricultural Science and Technology,

Vol.7 Issue.11, November-2020, pg. 132-144

ISSN: 2348-1358

Impact Factor: 6.057

NAAS Rating: 3.77

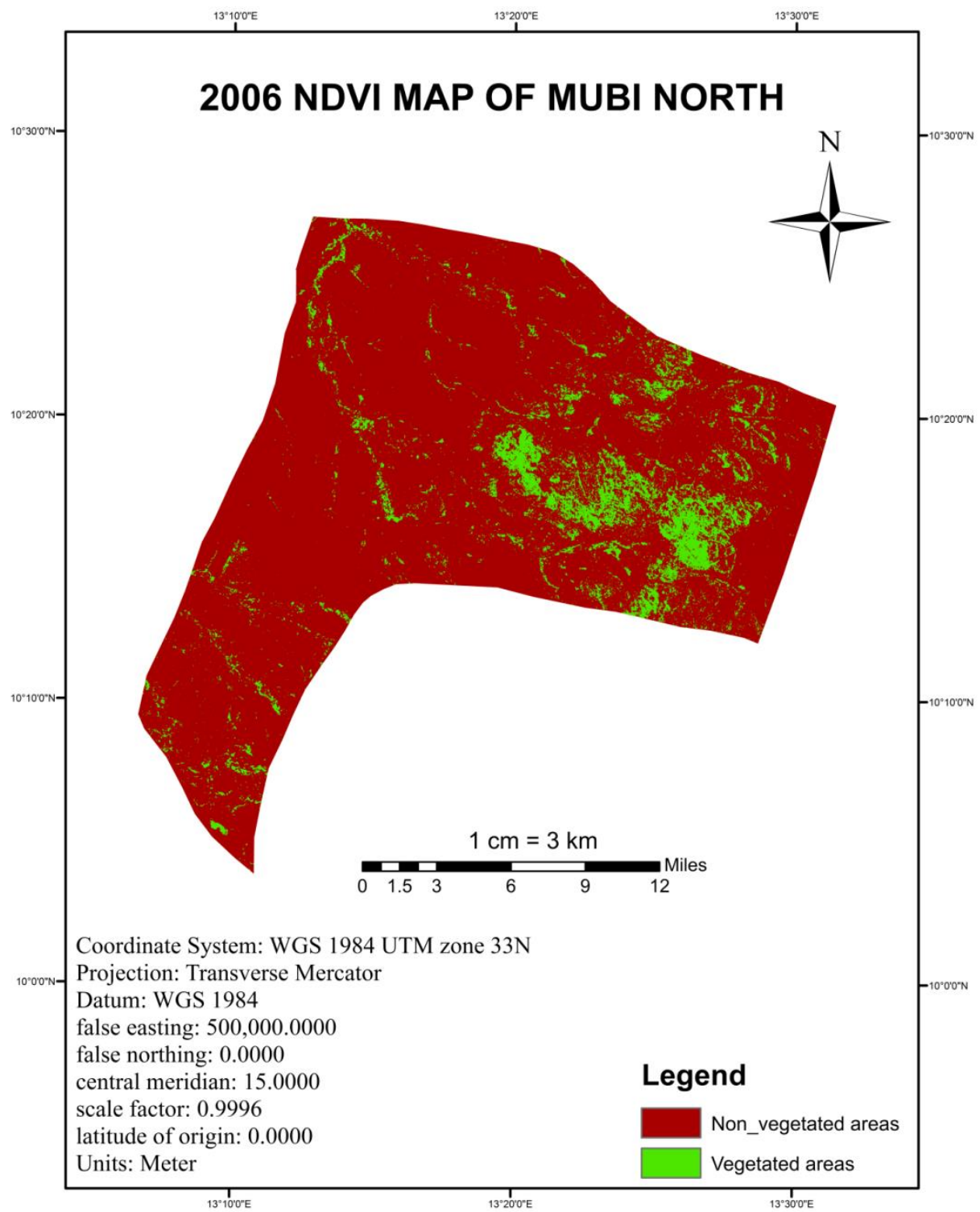




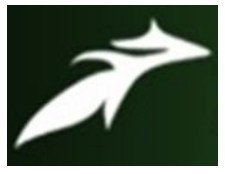

Gadona Enoch Alhamdu et al, International Journal of Advances in Agricultural Science and Technology,

Vol.7 Issue.11, November-2020, pg. 132-144

ISSN: 2348-1358

Impact Factor: 6.057

NAAS Rating: 3.77

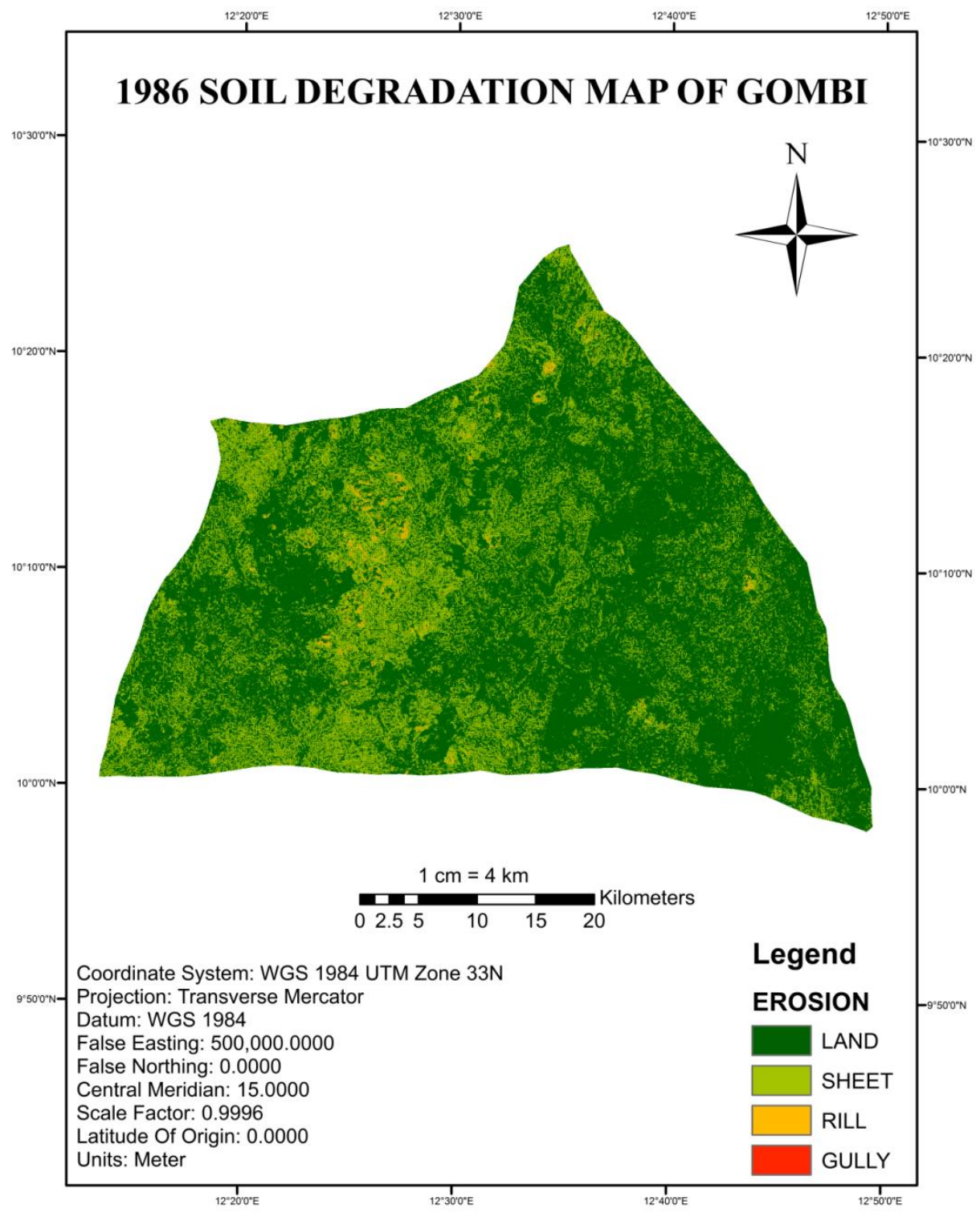




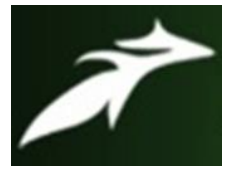

Gadona Enoch Alhamdu et al, International Journal of Advances in Agricultural Science and Technology,

Vol.7 Issue.11, November-2020, pg. 132-144

ISSN: 2348-1358

Impact Factor: 6.057

NAAS Rating: 3.77

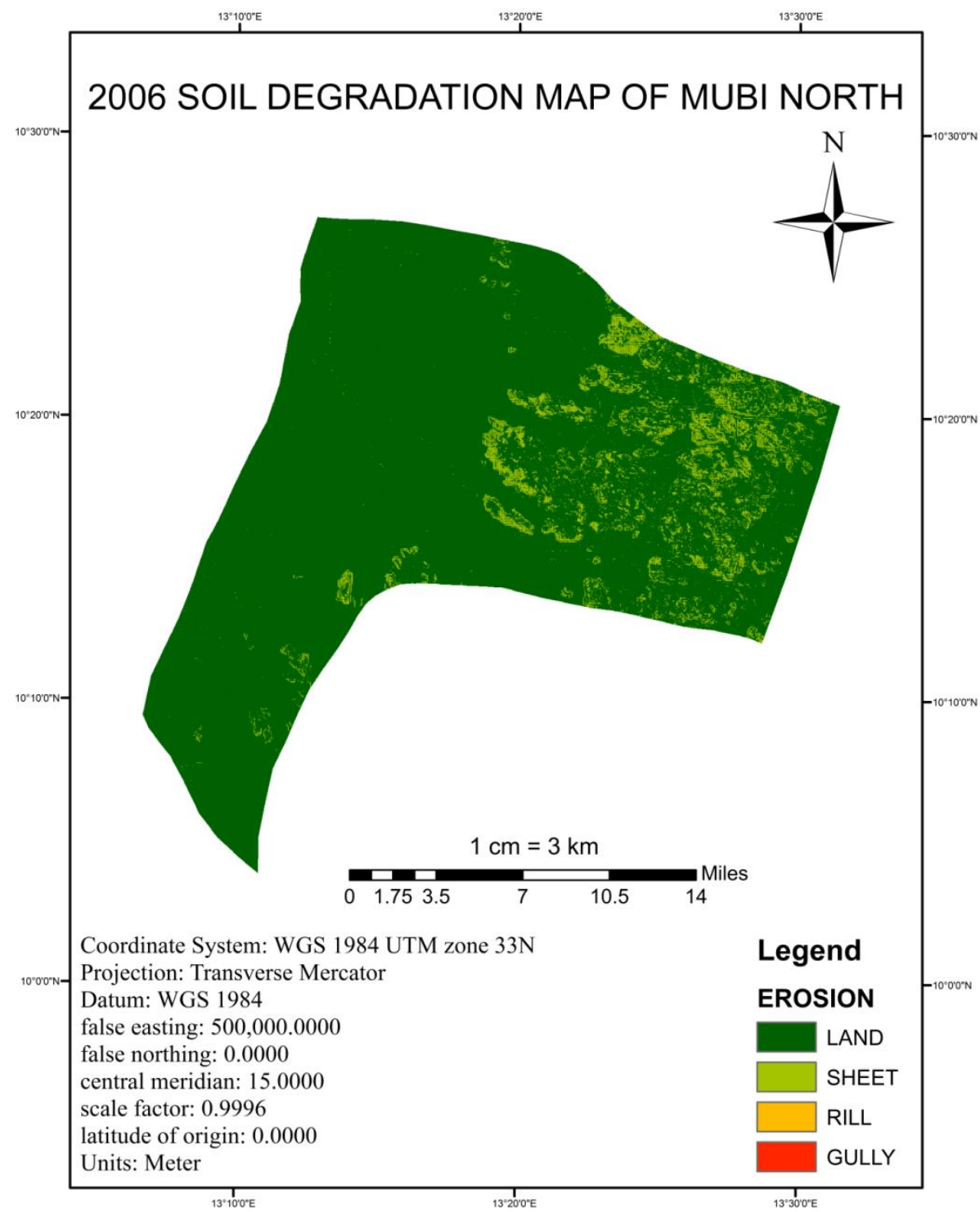




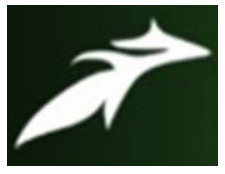

Gadona Enoch Alhamdu et al, International Journal of Advances in Agricultural Science and Technology,

Vol.7 Issue.11, November-2020, pg. 132-144

ISSN: 2348-1358

Impact Factor: 6.057

NAAS Rating: 3.77

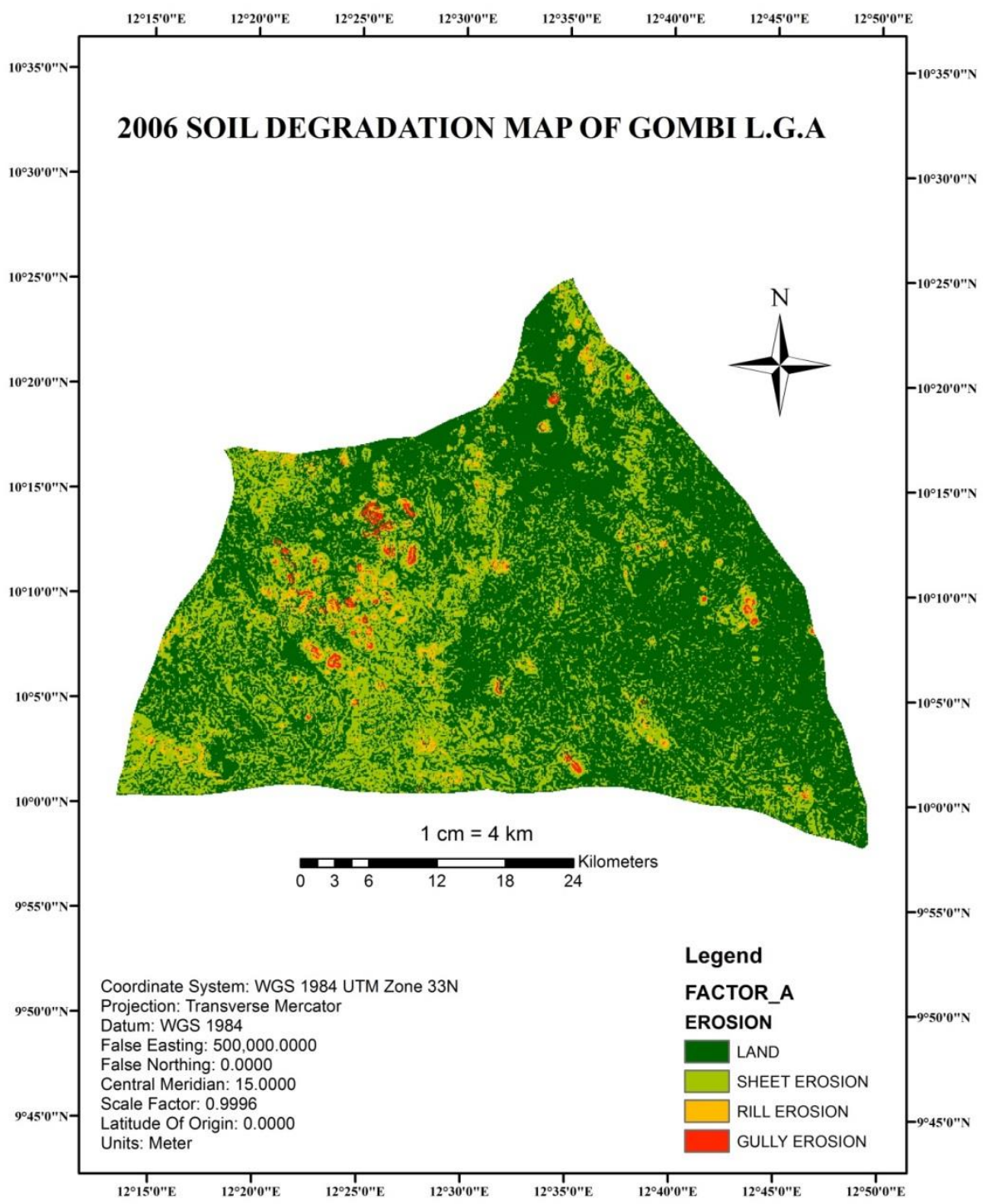




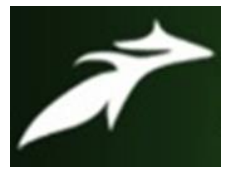

Gadona Enoch Alhamdu et al, International Journal of Advances in Agricultural Science and Technology,

Vol.7 Issue.11, November-2020, pg. 132-144

ISSN: 2348-1358

Impact Factor: 6.057

NAAS Rating: 3.77

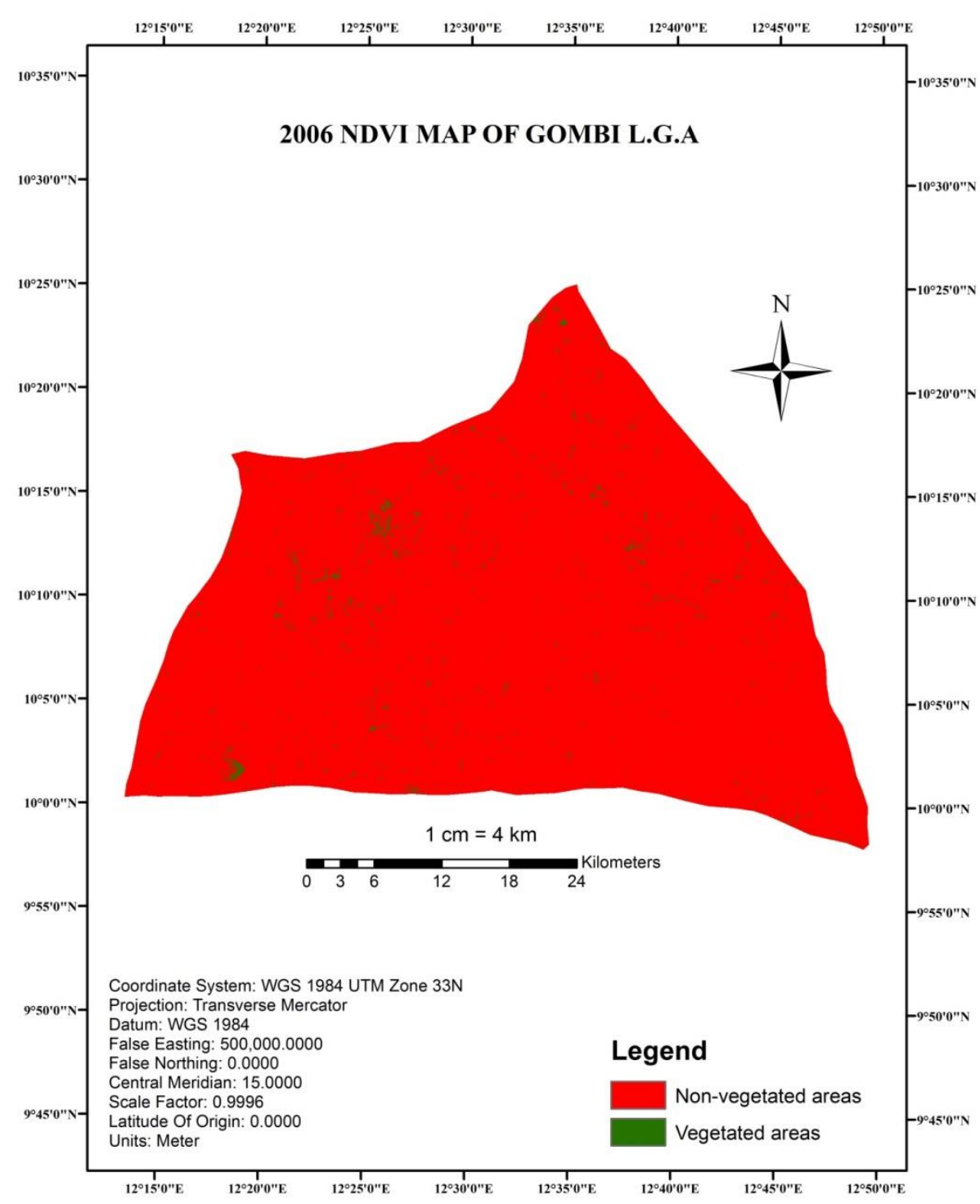

Figure 2 shows the soil degradation map of Mubi/North 1986. The soil map was produced from the soil Sharpe file downloaded and analyzed to show the soil erosion sites in Mubi/North. The result obtained showed the, soil degraded areas, sheet erosion is found in most parts of the area. Rill and gully erosion sites were not available in the area. This could be attributed to the thick vegetation cover as shown in the NDVI of 1986. 


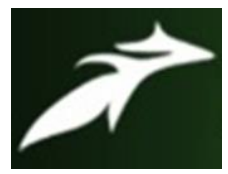

Gadona Enoch Alhamdu et al, International Journal of Advances in Agricultural Science and Technology, Vol.7 Issue.11, November-2020, pg. 132-144

ISSN: 2348-1358

Impact Factor: 6.057

NAAS Rating: 3.77

Figure 3 shows the soil degradation map of Mubi/North for 2006, from 1986 to 2006 (20yrs) the rich vegetation cover of 1986 shows the level of soil degradation that have occurred in the area. Result obtained shows increase in soil degradation in the eastern part of Mubi/North, this can be attributed to the nature of topography, climate change and the level of human impact on vegetation cover, the resulted in increase in sheet and rill erosion in the area.

Figure 4 shows the Normalized Difference Vegetation Index (NDVI) of Mubi/North for 1986. The NDVI is an indication of vegetation rigor and health that is used in determine cover management factor. The spatial distribution of NDVI revels that majority of the area is covered by healthy green vegetation cover in the eastern part, while scattered green vegetation cover is dotted in the other parts.

Figure 5 shows the NDVI of Mubi/North for 2006. From 1986 to 2006 there is decrease in vegetation cover, in 2006, scattered vegetation in the eastern part. Findings reveal that the decrease in vegetation cover is attributed to climate change, demographic factor, and the level of human impact on vegetation cover.

Figure 6 shows the soil degradation map of Gombi for 1986, the map shows the spatial distribution of soil degradation. The western part is degraded by sheet erosion with dotted rill erosion sites.

Figure 7 shows soil degradation map of Gaombi for 2006. From 1986 to 2006,the soil degradation rate have increased over the years, Gully erosion sites have emerged and scattered over the area with rill and sheet erosion. The level of soil erosion has increased in 2006.

Figure 8 shows the spatial distribution of NDVI in Gombi for 1986. Majority of the area is covered by healthy green vegetation as revealed by NDVI of 1986.

Figure 9 shows the spatial distribution of NDVI for 2006. The study reveals that the vegetation cover has decreased from 1986 to 2006 . This is attributed to climate change, demographic factor, and human impact on vegetation 


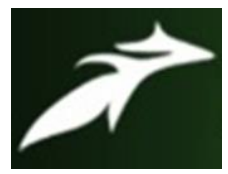

Gadona Enoch Alhamdu et al, International Journal of Advances in Agricultural Science and Technology, Vol.7 Issue.11, November-2020, pg. 132-144

\section{CONCLUSION}

ISSN: 2348-1358

Impact Factor: 6.057

NAAS Rating: 3.77

A detail mapping of soil degradation of Mubi/North and Gombi local government areas of Adamawa state, Nigeria was carried in this study using Remote Sensing (RS) and Geographic Information System (GIS) Techniques was employed. Several data sets that represent climate, soil and anthropogenic factors were used in analyzing and mapping soil degradation in the area. Mapping of soil degradation for 1986 to 2006 and the Normalized Difference Vegetation Index (NDVI) of 1986 to 20006 was carried out. The systematic efforts in the application of Remote Sensing technology in the study of natural resources has resulted in the development of wellestablished methodology for mapping soil degradation in cost effective manner. There is considerable increase in soil degradation from 1986 to 2006 as a result of demographic and climatic factors. In view of these findings, this research study recommends Practical and Sustainable Land Management Practice for sustainable environmental management that would reduce the impact of soil degradation to sustain the environment and improve crop yield.

\section{REFERENCES}

[1]. Ann, V.D (2010) Soil Degradation: International Center for Erotology. Universities Gest

[2]. Freddy, O.N (2010) Land Degradation Assessment Indicators and LADA Project. Scope Soil Conservation and Projection from Europe. Land and Water Development Division Italy.

[3]. Gessed,G.D; Kilka,A and Hurni (2009)Assessment of Soil Erosion and Soil Conservation Planning In Ayoubi S.F; Khormali, K.L; Sahrawat A. Cand Rodrigne de Lima(2011) Assessing Impacts of Land Use Change on Soil Quality Indicators in a Loessial Soil in Golestan province; Iran journal of Agricultural science technology 13: 727-742.

[4]. La, R (eds) (1986) Soil Quality and Soil Erosion and Water Conservation Society, SRC Press USA.

[5]. Mick,L.(2014) Land Degradation: The Australlian Collaboration: A Collaboration of National Community Organizations: www.australliancollaboration.con.al. 